\title{
Association between Angiotensin II Type 1 Receptor Polymorphism and Sudden Cardiac Death in Myocardial Infarction
}

\author{
Peter Kruzliak, ${ }^{1,2}$ Gabriela Kovacova, ${ }^{3}$ Olga Pechanova, ${ }^{1}$ and Stefan Balogh ${ }^{3}$ \\ ${ }^{1}$ Institute of Normal and Pathological Physiology and Centre of Excellence for Regulatory Role of Nitric Oxide in Civilisation Diseases, \\ Slovak Academy of Sciences, Sienkiewiczova 1, 81371 Bratislava, Slovakia \\ ${ }^{2}$ Department of Cardiovascular Diseases, International Clinical Research Center, St. Anne's Faculty Hospital and Masaryk University, \\ Pekarska 53, 60200 Brno, Czech Republic \\ ${ }^{3} 5$ th Department of Internal Medicine, University Hospital and Medical Faculty, Comenius University, \\ Ruzinovska 6, 82606 Bratislava, Slovakia \\ Correspondence should be addressed to Peter Kruzliak; peter.kruzliak@savba.sk
}

Received 17 June 2013; Accepted 21 August 2013

Academic Editor: Grant Izmirlian

Copyright (c) 2013 Peter Kruzliak et al. This is an open access article distributed under the Creative Commons Attribution License, which permits unrestricted use, distribution, and reproduction in any medium, provided the original work is properly cited.

Objective. The renin-angiotensin system is involved in the pathogenesis of coronary artery disease and myocardial infarction (MI). Angiotensin II (Ang II) has many adverse effects such as vasoconstriction and vascular remodeling, and these actions are mediated by the angiotensin II type 1 receptor (AT1R). Patients and Methods. A total of 1376 patients were recruited from January 2010 to April 2012. The study group consisted of 749 patients with ACS (317 females and 432 males) and of 627 healthy controls. Results. The ACS patients demonstrated a lower proportion of AA genotypes and AC genotypes but higher proportions of CC genotypes than the control population. The AT1R CC genotype conferred a 2.76-fold higher risk of MI compared with the genotype AC and AA. In addition, the CC genotype was also associated with a 4.08 times higher risk of left anterior descending artery infarction and a 3.07 times higher risk of anterior wall infarction. We also found that the CC genotype was independently associated with sudden cardiac death. In Summary. This study demonstrated that the AT1R CC genotype is an independent risk factor for ACS incidence, and this genotype is associated with a greater ACS severity and greater risk of sudden cardiac death.

\section{Introduction}

Acute myocardial infarction (MI) is defined as death or necrosis of myocardial cells due to an inadequate amount of oxygen supply to the heart. The classical symptoms of MI are shortness of breath, anxiety, chest pain typically radiating to the left arm or left side of the neck, vomiting, and palpitations. Important risk factors include previous history of vascular disease, such as atherosclerosis, angina, previous heart attack or stroke, and age-especially men over 40 and women over 50 years [1].

The renin-angiotensin system plays an important role in blood pressure regulation and homeostasis, and it is involved in the pathogenesis of coronary artery disease and MI [25]. Angiotensin II (Ang II) is a key component of the reninangiotensin system formed by action of the angiotensinconverting enzyme on the precursor molecule angiotensin I. It has many adverse effects, such as vasoconstriction, cellular proliferation, vascular remodeling, and aldosterone secretion, and it contributes to endothelial dysfunction and atherosclerosis by promotion of oxidative stress $[6,7]$. All these actions are mediated by the angiotensin II type 1 receptor (AT1R).

The AT1R gene is located on chromosome 3q21-q25, its length is $>55 \mathrm{~kb}$, and it is composed of five exons and four introns. It belongs to the superfamily of G-protein-coupled 
receptors. The gene polymorphism in the present study was located at the untranslated $3^{\prime}$ region (A1166C), corresponding to an $\mathrm{A} \rightarrow \mathrm{C}$ transversion in the position of nucleotide 1166 of the mRNA sequence, resulting in an $\mathrm{A} / \mathrm{C}$ polymorphism $[8,9]$.

Studies have been carried out to find an association between the A/C polymorphism of AT1R and MI. Some studies have revealed that the CC genotype is not associated with MI $[10,11]$, while others have observed that the CC homozygous genotype is associated with $\mathrm{MI}$ and coronary heart disease [12-14]. Tiret et al. found significant association between angiotensin type II receptor polymorphism and acute coronary syndrome. On the other hand, in the study by Gardemann et al. There was no detected association between angiotensin II type 1 receptor $A 1166 C$ gene polymorphism and coronary artery disease. In view of these controversial reports, the present study was aimed at assessing the association of the A1166C polymorphism of the AT1 receptor gene with MI and sudden cardiac death.

\section{Methods}

The study was designed as a case-control study. Aim of this study was to determine the prevalence of polymorphisms of the gene for angiotensin II type 1 receptor and compare it with the healthy population.

A total of 1376 patients were recruited from January 2010 to April 2012 in the 5th Department of Internal Medicine, University Hospital Bratislava, Slovak Republic. The study conforms with the Declaration of Helsinki and Institutional Ethics Committee of the University Hospital Bratislava, and written informed consent was obtained from all the subjects.

The study group consisted of 749 patients with acute coronary syndrome (ACS patients-317 females and 432 males) with a mean age of $61.4 \pm 9.7$ years. All patients were admitted with acute coronary syndrome, and on the basis of typical ECG changes, elevated cardiac markers, clinical history, and coronary angiography (50\% stenosis affected at least one major coronary vessel) the diagnosis was confirmed as MI. Blood samples were collected from patients after 12 to 14 hours of fasting. Simultaneously, blood samples were collected from 627 healthy, age- and sexmatched controls (male : female $=354: 273$ ) with mean age 54 \pm 10.3 . All controls were nonhypertensive and nondiabetic. Information on height, weight, body mass index, cigarette smoking, hypertension, diabetes, family history of coronary artery disease, and diabetes was collected using a structured questionnaire. Acute coronary syndrome was diagnosed on the basis of recommendations of European Society of Cardiology (ESC) $[15,16]$. Hypertension was defined according to ESC guidelines as systolic blood pressure $>140 \mathrm{mmHg}$ and/or diastolic blood pressure $>90 \mathrm{mmHg}$, based on the average of two blood pressure measurements, or a patient's self-reported history of hypertension [17]. Diabetes was diagnosed if fasting plasma glucose was $>110 \mathrm{mg} / 100 \mathrm{~mL}$ or the patient was on antidiabetic medications [18]. The reference value for cholesterol was $200 \mathrm{mg} / \mathrm{dL}$ and for triglycerides 130$150 \mathrm{mg} / \mathrm{dL}$. Dyslipidemia was diagnosed according to ESC guidelines [19]. Coronary angiography was used to confirm
TABLE 1: Demographic and clinical characteristics of ACS patients and healthy controls.

\begin{tabular}{lcc}
\hline & $\begin{array}{c}\text { ACS patients } \\
(n=749)\end{array}$ & $\begin{array}{c}\text { Healthy controls } \\
(n=627)\end{array}$ \\
\hline Mean age (years) & $61.4 \pm 9.7$ & $54 \pm 10.3$ \\
Sex (male/female) & $432 / 317$ & $354 / 273$ \\
BMI $\left(\mathrm{kg} / \mathrm{m}^{2}\right)$ & $28.4 \pm 4.6$ & $27.3 \pm 5.4$ \\
Smokers $n(\%)$ & $328(43.79 \%)$ & $163(25.99 \%)$ \\
Fasting glucose (mmol/L) & $6.4 \pm 1.4$ & $4.9 \pm 1.2$ \\
Diabetes mellitus $(\%)$ & $329(43.65 \%)$ & $0(0 \%)$ \\
HbAlc $(\%)$ & $7.3 \pm 2.4$ & $3.4 \pm 1.5$ \\
Arterial hypertension $n(\%)$ & $377(50.33 \%)$ & $0(0 \%)$ \\
Systolic blood pressure (mmHg) & $154 \pm 16.4$ & $124 \pm 8.6$ \\
Diastolic blood pressure (mmHg) & $93.6 \pm 10.4$ & $82.3 \pm 6.7$ \\
Dyslipidemia (\%) & $213(28.43 \%)$ & $49(7.81 \%)$ \\
Total cholesterol (mmol/L) & $8.2 \pm 1.7$ & $4.3 \pm 0.9$ \\
HDL-cholesterol (mmol/L) & $1.5 \pm 0.2$ & $1.3 \pm 0.3$ \\
LDL-cholesterol (mmol/L) & $5.9 \pm 1.6$ & $2.7 \pm 0.9$ \\
Triglycerides (mmol/L) & $2.1 \pm 0.4$ & $1.3 \pm 0.2$ \\
\hline
\end{tabular}

the presence or assess the extension of coronary artery disease, and patients with obstructive lesions greater than $50 \%$ were selected for the study. Total cholesterol and triglyceride plasma levels were performed on automated analyzer Hitachi 917 Germany, using commercial kits supplied by Roche diagnostics (Mannheim Germany). Demographic and clinical characteristics are in Table 1.

2.1. Genotyping Methods. Blood was collected in ethylenediaminetetraacetic acid. DNA was isolated from leukocytes according to standard procedures using proteinase K. DNA segments were amplified by polymerase chain reaction (PCR) in a total volume of $15 \mu \mathrm{L}$ containing $0.1 \mu \mathrm{L}$ Taq, $1.5 \mu \mathrm{L}$ buffer, $2.5 \mu \mathrm{L} \mathrm{MgCl}_{2}, 0.5 \mu \mathrm{L}$ dNTP, $0.5 \mu \mathrm{L}$ of each primer, and $7.4 \mu \mathrm{L}$ $\mathrm{H}_{2} \mathrm{O}$. The primers used were $5^{\prime}$-AGAAGCCTGCACCATGTTTT- $3^{\prime}$ (sense) and $5^{\prime}$-TGTGGCTTTGCTTTGTCTTG$3^{\prime}$ (antisense). The reaction conditions were as follows: initial denaturation $95^{\circ} \mathrm{C} 5 \mathrm{~min}$, then 33 cycles of denaturation $94^{\circ} \mathrm{C}$ for $30 \mathrm{~s}$, annealing $53^{\circ} \mathrm{C}$ for $25 \mathrm{~s}$, elongation $72^{\circ} \mathrm{C}$ for $25 \mathrm{~s}$, final elongation $72^{\circ} \mathrm{C}$ for $10 \mathrm{~min}$, and cooling $10^{\circ} \mathrm{C}$ for $10 \mathrm{~min}$. The PCR product ( $233 \mathrm{bp}$ ) was digested by $5 \mathrm{U}$ of Dde I for $12 \mathrm{~h}$. The fragments were separated by electrophoresis using $3 \%$ agarose gel at $85 \mathrm{~V}$ and visualized by ethidium bromide staining under UV light. The AA variant was detected as one fragment (233 bp), AC as three fragments (233, 118, $115 \mathrm{bp})$, and $\mathrm{CC}$ as two fragments (118 and $115 \mathrm{bp}$ ).

2.2. Statistical Methods. Patient's age at diagnosis was recorded as a continuous variable and shown as mean \pm standard deviation. The odds ratios (ORs) and corresponding 95\% confidence intervals (CIs) for assessing the effect of the AT1R A/C genotype distribution and allele frequencies on ACS were calculated by logistic regression analysis with adjustment for relevant significant variables (Tables 4 and 5). All the statistical analyses were performed using SPSS 16.0 
and Excel 2007. All statistical tests were two sided, and the level of significance was set at 0.05 .

\section{Results}

Comparisons of the distributions of demographic and relevant clinical risk factors between ACS patients and healthy controls and the estimated OR for each risk factor are listed in Table 2. There was no significant difference in either the age or gender distribution between the two groups included. The prevalence of arterial hypertension $(\mathrm{AH})$, dyslipidemia, and diabetes mellitus (DM) was significantly increased in acute MI patients as compared to healthy controls. Diastolic blood pressure (DBP) and systolic blood pressure (SBP), total cholesterol, and LDL-cholesterol were also higher in MI patients than in healthy controls. In the univariate logistic regression model, older age, higher systolic blood pressure or diastolic blood pressure and the presence of diabetes mellitus were found to be significant risk factors for ACS.

The distribution of the AT1R genotypes was in agreement with the Hardy-Weinberg equilibrium. The frequency of the A1166C polymorphism was significantly different between patients and controls $(P=0.024)$. Table 3 illustrates that ACS patients demonstrated a lower proportion of AA genotypes (32.17\%) but higher proportions of CC genotypes $(23.79 \%)$ than the control population (AA 50.39\%, AC 42.90\%, CC $6.69 \%)$. The AT1R CC genotype conferred a 2.76-fold risk of ACS compared with the genotype AC and AA (95\% CI: 1.07-6.49, $P=0.004$, logistic regression). After controlling for other risk factors, the CC genotype was still significantly associated with ACS, conferring a 4 times higher risk (OR = 4.295; 95\% CI: 1.436-12.851). To further evaluate the etiologic effects of ATR1 polymorphisms in ACS, we analyzed the association between AT1R genotypes and different ACS manifestations (UAP and acute MI), relevant clinical risk factors (hypertension, diabetes mellitus, hypercholesterolemia, systolic blood pressure, diastolic blood pressure, and body mass index), clinical history (heart failure, CAD, MI, and family history), and history of smoking.

As shown in Table 4, the CC genotype conferred a significant 3.35-fold risk of acute MI (Table 2. 95\% CI: 1.111$10.115, P=0.032$, logistic regression); however, there was no significant association between A1166C polymorphism and any other risk factor among the recruited ACS group. Subsequent analyses evaluated the possible influence of A1166C polymorphism on final ACS clinical outcome. The association between AT1R A/C polymorphism and ACS severity and mortality was determined. Interestingly, ACS patients with the CC genotype had a significantly higher risk of presenting with a greater number of stenosed vessels, with a 3.87 times increased risk of stenosis in all three coronary arteries (Table 5, 95\% CI: 1.09-13.81, $P=0.037$, logistic regression). In addition, the CC genotype was also associated with a 4.08-fold risk of left anterior descending artery infarction (Table 5, 95\% CI: 1.04-9.12, $P=0.042$ ) and a 3.07-fold risk of anterior wall infarction (Table 5, 95\% CI: 1.04-9.12, $P=0.024)$. The CC genotype was found to be independently associated with sudden cardiac death in patients with ACS (Table 5, OR = 6.48, 95\% CI: 1.04-40.60, $P=0.036$, logistic regression).

\section{Discussion}

The AT1R is a major component of the renin-angiotensin system. It mediates most of the classical and biological functions of angiotensin II [20]. It belongs to the G-proteincoupled receptor superfamily and is a peptide containing 360 amino acids. Binding of angiotensin II to the AT1R in vascular smooth muscle cells results in phospholipase C-mediated generation of inositol 1,4,5-trisphosphate and diacylglycerol. Inositol 1,4,5-trisphosphate mobilizes calcium from the endoplasmic reticulum, and calcium and diacylglycerol activate enzymes, including protein kinase $\mathrm{C}$ and calcium/calmodulin-activated kinases. Ang II acts as a mitogen in vascular smooth muscle cells by activating several signaling pathways, such as that of phospholipase C, phospholipase A2, and phospholipase $\mathrm{D}$, as well as activating a large number of kinases, such as tyrosine kinases, mitogen-activated protein kinases (MAPKs), c-src kinase, Janus-associated tyrosine kinase, and receptors with tyrosine-kinase activity. Ang II also stimulates transcription factors, such as the activating protein, signal transduction and transcription activators (STATs), and the nuclear factor kappa B (Nf $\kappa$ B) $[6,20-22]$. The AT1R has been shown to be involved in the process of vascular hypertrophy, sodium retention, cardiac remodeling, hypertension and fibrinogenesis [23-25]. The AT2 receptor plays a counterregulatory role $[6,26,27]$.

As described by Duncan et al. (2001), many polymorphisms of the AT1R gene have been identified, but the A1166C polymorphism has been the most extensively studied. The physiological significance of this polymorphism is uncertain because of its location in the $3^{\prime}$-untranslated region of the gene [28].

There are controversial reports regarding the role of $A T 1 R$ gene A/C polymorphism as a risk factor for MI. Some studies have reported a positive association [12-14], while others could not find any association [10, 11, 28, 29].

In the study by Berge et al. (1997), 247 survivors of myocardial infarction (MI) were compared to 384 controls with respect to distribution of genotypes and gene frequencies in the A1166C polymorphism at the AT1R locus. No differences in allele frequencies or genotype distribution were observed when all patients were compared with all controls. When they compared CC homozygotes with the combined group of CA heterozygotes and AA homozygotes (CA/AA), a difference in borderline significance between the MI group and controls was observed $(P=0.05)$. In males alone, this difference was much more pronounced because of the larger proportion of males with the CC genotype in MI cases than in male controls $(P=0.01)$. No significant differences were observed between female cases and controls. When was the subjects subdivided into a "low-risk" and a "high-risk" group, based on levels of apolipoprotein B (apoB) and body mass index (BMI), and whether or not the person used lipidlowering drugs, the frequency of CC homozygotes in male cases of the "low-risk" group differed significantly compared to the frequency in male controls of the "low-risk" group 
TABLE 2: Distributions of demographic and relevant clinical risk factors between ACS patients and healthy controls and the estimated OR for each risk factor.

\begin{tabular}{|c|c|c|c|c|c|c|}
\hline Subject characteristics & $\begin{array}{l}\text { ACS patients } \\
(n=749)\end{array}$ & $\begin{array}{l}\text { Controls } \\
(n=627)\end{array}$ & $\begin{array}{l}\text { Univariate analysis } \\
\text { OR }(95 \% \text { CI })\end{array}$ & $P$ & $\begin{array}{c}\text { Multivariate analysis } \\
\text { OR }(95 \% \mathrm{CI})\end{array}$ & $P$ \\
\hline \multicolumn{7}{|l|}{ AT1R-genotypes } \\
\hline AA & 241 & 316 & 1 (ref.) & & 1 (ref.) & \\
\hline $\mathrm{AC}$ & 329 & 269 & $1.17(0.79-2.1)$ & 0.603 & $1.284(0.595-2.773)$ & 0.524 \\
\hline $\mathrm{CC}$ & 179 & 42 & $2.76(1.07-6.49)$ & 0.004 & $4.295(1.436-12.851)$ & 0.009 \\
\hline Mean age & $61.4 \pm 9.7$ & $54 \pm 10.3$ & $0.75(0.24-2.76)$ & 0.98 & $1.25(0.46-2.96)$ & 0.425 \\
\hline Sex-male & 432 & 354 & $1.53(0.89-2.62)$ & 0.123 & - & - \\
\hline Systolic blood pressure $\geq 140 \mathrm{mmHg}$ & 327 & 97 & $9.73(3.44-17.16)$ & $<0.001$ & $6.97(2.53-14.37)$ & 0.003 \\
\hline Diastolic blood pressure $\geq 90 \mathrm{mmHg}$ & 94 & 23 & $5.92(1.47-9.81)$ & 0.002 & $3.65(1.45-10.40)$ & 0.004 \\
\hline Diabetes mellitus & 329 & 0 & $14.22(4.98-25.26)$ & $<0.001$ & $12.75(3.41-23.58)$ & 0.001 \\
\hline
\end{tabular}

TABLE 3: Distribution of AT1R A/C gene polymorphisms.

\begin{tabular}{|c|c|c|c|}
\hline $\begin{array}{l}\text { ATR1 A1166C } \\
\text { Polymorphism }\end{array}$ & $\begin{array}{l}\text { ACS patients } \\
\quad(n=749)\end{array}$ & $\begin{array}{l}\text { Healthy controls } \\
\quad(n=627)\end{array}$ & OR \\
\hline CC (\%) & $179(23.89 \%)$ & $42(6.69 \%)$ & $\begin{array}{c}\mathrm{OR}=2.76 \\
(1.07-6.49) \\
P=0.004\end{array}$ \\
\hline $\mathrm{AC}(\%)$ & $329(43.92 \%)$ & $269(42.90 \%)$ & $\begin{array}{c}\mathrm{OR}=1.17 \\
(0.79-2.1) \\
P=0.603\end{array}$ \\
\hline $\mathrm{AA}(\%)$ & 241 (32.17\%) & $316(50.39 \%)$ & $\begin{array}{c}\mathrm{OR}=0.43 \\
(0.23-0.76) \\
P=0.015\end{array}$ \\
\hline C (\%) & $508(67.82 \%)$ & $311(49.60 \%)$ & $\begin{array}{c}\mathrm{OR}=1.68 \\
(1.17-2.41) \\
P=0.004\end{array}$ \\
\hline A (\%) & $570(76.10 \%)$ & $585(93.30 \%)$ & $\begin{array}{c}\mathrm{OR}=0.59 \\
(0.41-0.85) \\
P=0.004\end{array}$ \\
\hline
\end{tabular}

$(P<0.001)$. No interaction between the insertion/deletion (I/D) polymorphism at the angiotensin I-converting enzyme (ACE) locus and the polymorphism at the AT1R locus was detected [13].

Tiret et al. (1994) described a synergic association of DD (I/D) homozygotes of the ACE and CC gene of the A1166C polymorphism of the $A T 1 R$ gene. For these authors, this gene interaction of risk for myocardial infarction might suggest a possible epistatic effect of the two genes, assuming that the $\mathrm{C}$ allele of $A T 1 R$ is associated with a modified response of the angiotensin II receptor, thus modulating the possible risk conferred by the D allele of the ACE gene [14]. Álvarez et al. (1998) in a young Spanish population developed a casecontrol study to determine the I/D genotypes of the ACE gene and $\mathrm{A} 1166 \mathrm{C}$ of the gene of receptor 1 of angiotensin II. Separately, no association was observed; but the ACE-DD and AT1R-CC genotypes interacting synergically were associated with coronary artery disease $(\mathrm{OR}=5.32$; 95\% CI, 1.45-19.51) [30].

In contrast, Gardemann et al. (1998) found no synergic interaction between the polymorphic variants of the $A C E$ and
$A T 1 R$ genes and coronary artery disease in 2244 Caucasian men [31].

In this study no association was detected between angiotensin II type 1 receptor $A 1166 C$ gene polymorphism and coronary artery disease. Similarly, there was no link to myocardial infarction. Rice et al. (1999) demonstrated the absence of a synergic association with myocardial infarction, although they found a weak association between some genotypes (AC/II and CC/DD) and coronary stenosis [32].

de Araújo et al. (2004) found no association between A1166C polymorphism of the AT1R gene and the severity of the coronary lesions, when comparing the genotypes CC versus $\mathrm{AC}$ versus $\mathrm{AA}$ [11]. It was a prospective cross-sectional study with 110 consecutive patients $(66.6 \%$ of the male sex and $36.4 \%$ of the female sex, mean age $=61.82 \pm$ 10.81 years) diagnosed with acute myocardial infarction based on clinical, electrocardiographic, and enzymatic data and confirmed through coronary angiography. The control group comprised 104 patients (57.7\% of the female sex and $42.3 \%$ of the male sex, mean age $=56.69 \pm 11.52$ years) who were renal transplant donors or had valvular heart disease or atypical chest pain but had no lesions in the coronary arteries on coronary angiography. The genotypic frequency in the infarcted patients was as follows: $\mathrm{AA}=54.5 \%$; $\mathrm{AC}=35.5 \%$; and $\mathrm{CC}=10 \%$, which was similar and nonsignificant in regard to that in the control group without myocardial infarction $(P=0.83)$. No risk increase occurred for acute myocardial infarction when comparing the genotypes as follows: CC versus $\mathrm{AA}(\mathrm{OR}=1.35$; 95\% $\mathrm{CI}=0.50-3.59)$; $\mathrm{AC}$ versus $\mathrm{AA}$ $(\mathrm{OR}=1.03 ; 95 \% \mathrm{CI}=0.58-1.84)$; and $\mathrm{AA}+\mathrm{AC}$ versus $\mathrm{AA}$ $(\mathrm{OR}=1.33$; 95\% CI $=0.51-3.45)$.

Based on these discrepancies, we decided to study the association between AT1R A/C polymorphism and myocardial infarction in the Slovak population. To our knowledge, no study dealing with the relationship between the AT1R $\mathrm{A} / \mathrm{C}$ polymorphism and sudden cardiac death has as yet been published. For this reason we intended to determine whether AT1R A/C polymorphism was an independent risk factor for sudden cardiac death.

This study demonstrated that the CC genotype acted as an independent risk factor for ACS and in particular for 
TABLE 4: Association between AT1R A/C polymorphism and ACS risk factors.

\begin{tabular}{|c|c|c|c|c|c|c|c|}
\hline $\begin{array}{l}\text { ATR1 genotypes } \\
\text { ACS risk factors }\end{array}$ & $\begin{array}{c}\mathrm{AA}(n=241) \\
n\end{array}$ & $\begin{array}{c}\mathrm{AC}(n=329) \\
n\end{array}$ & $\begin{array}{c}\text { Univariate } \\
\text { OR ( } 95 \% \mathrm{CI})\end{array}$ & $P$ & $\begin{array}{c}\mathrm{CC}(n=179) \\
n\end{array}$ & $\begin{array}{c}\text { Univariate } \\
\text { OR ( } 95 \% \mathrm{CI})\end{array}$ & $P$ \\
\hline UAP & 145 & 214 & $1.37(0.31-2.18)$ & 0.273 & 66 & $1.24(0.73-2.98)$ & 0.148 \\
\hline AMI & 96 & 115 & $1.21(0.51-2.834)$ & 0.670 & 113 & $3.35(1.11-0.12)$ & 0.032 \\
\hline Age (mean) & $65.7 \pm 11.1$ & $61.2 \pm 13.5$ & $0.98(0.95-1.01)$ & 0.232 & $60.3 \pm 14.1$ & $0.97(0.94-1.01)$ & 0.149 \\
\hline Sex-male & 137 & 146 & $1.35(0.43-7.54)$ & 0.450 & 149 & $1.18(0.38-3.72)$ & 0.776 \\
\hline Hypertension & 131 & 143 & $0.57(0.23-1.44)$ & 0.236 & 103 & $0.40(0.14-1.21)$ & 0.104 \\
\hline Diabetes mellitus & 117 & 137 & $0.88(0.36-2.16)$ & 0.780 & 75 & $1.36(0.43-4.33)$ & 0.603 \\
\hline Hypercholesterolemia & 54 & 107 & $0.63(0.21-1.87)$ & 0.403 & 52 & $0.92(0.23-3.68)$ & 0.905 \\
\hline $\operatorname{BMI}\left(\mathrm{kg} / \mathrm{m}^{2}\right) \geq 27$ & 17 & 26 & $2.16(0.65-9.33)$ & 0.151 & 13 & $1.67(0.22-9.73)$ & 0.622 \\
\hline Systolic blood pressure $\geq 140 \mathrm{mmHg}$ & 109 & 131 & $0.50(0.20-1.25)$ & 0.137 & 87 & $1.13(0.39-3.24)$ & 0.822 \\
\hline Diastolic blood pressure $\geq 90 \mathrm{mmHg}$ & 28 & 40 & $0.36(0.12-1.10)$ & 0.143 & 26 & $1.18(0.38-3.72)$ & 0.776 \\
\hline Heart failure history & 21 & 32 & $0.88(0.31-2.51)$ & 0.817 & 16 & $1.59(0.49-5.18)$ & 0.445 \\
\hline CAD history & 143 & 204 & $1.67(0.37-2.07)$ & 0.755 & 107 & $0.95(0.17-3.62)$ & 0.257 \\
\hline MI history & 36 & 42 & $1.23(0.28-5.51)$ & 0.785 & 27 & $1.08(0.17-7.00)$ & 0.936 \\
\hline Family history of ACS & 12 & 17 & $0.35(0.03-4.01)$ & 0.399 & 9 & $0.80(0.07-9.30)$ & 0.855 \\
\hline Family history of diabetes & 21 & 33 & $0.47(0.07-2.03)$ & 0.576 & 17 & $0.97(0.25-2.46)$ & 0.767 \\
\hline Smoking & 105 & 136 & $0.89(0.38-2.09)$ & 0.793 & 87 & $1.28(0.45-3.64)$ & 0.639 \\
\hline
\end{tabular}

UAP: unstable angina pectoris, AMI: acute myocardial infarction, BMI: Body mass index, and CAD: coronary artery disease.

TABLE 5: Association between AT1R A/C polymorphism and ACS severity and myocardial infarct related sudden cardiac death.

\begin{tabular}{|c|c|c|c|c|c|c|c|}
\hline $\begin{array}{l}\text { ACE genotypes } \\
\text { Clinical symptoms }\end{array}$ & $\begin{array}{c}\mathrm{AA}(n=241) \\
n\end{array}$ & $\begin{array}{c}\mathrm{AC}(n=329) \\
n\end{array}$ & $\begin{array}{c}\text { Univariate } \\
\text { OR }(95 \% \text { CI })\end{array}$ & $P$ & $\begin{array}{c}\mathrm{CC}(n=179) \\
n\end{array}$ & $\begin{array}{c}\text { Univariate } \\
\text { OR }(95 \% \text { CI) }\end{array}$ & $P$ \\
\hline \multicolumn{8}{|l|}{ Stenosis numbers } \\
\hline 0 or 1 vessel & 97 & 149 & $1.384(0.679-3.243)$ & 0.665 & 51 & $2.154(0.821-4027)$ & 0.294 \\
\hline 2 vessels & 76 & 107 & $1.267(0.435-3.686)$ & 0.665 & 49 & $2.006(0.729-5.515)$ & 0.178 \\
\hline 3 vessels & 68 & 73 & $2.111(0.530-8.407)$ & 0.289 & 79 & $3.870(1.085-13.812)$ & 0.037 \\
\hline $\begin{array}{l}\text { Infarcted left anterior } \\
\text { descending artery }\end{array}$ & 109 & 154 & $2.166(0.912-5.144)$ & 0.080 & 117 & 4.080 (1.041-9.118) & 0.024 \\
\hline Infarcted left circumflex & 93 & 124 & $1.477(0.630-3.460)$ & 0.370 & 76 & $1.744(0.292-2.436)$ & 0.753 \\
\hline Infarcted right coronary & 98 & 137 & $1.174(0.498-2.764)$ & 0.714 & 74 & $0.779(0.275-2.211)$ & 0.639 \\
\hline Anterior infarction wall & 113 & 157 & $1.727(0.279-3.893)$ & 0.514 & 119 & $3.073(1.039-9.091)$ & 0.043 \\
\hline Inferior infarction wall & 97 & 126 & $2.429(0.609-9.679)$ & 0.208 & 81 & $2.386(0.482-11.803)$ & 0.286 \\
\hline Sudden cardiac death & 4 & 6 & $1.489(0.258-8.595)$ & 0.656 & 13 & $6.484(1.036-40.598)$ & 0.036 \\
\hline
\end{tabular}

acute MI (Table 2). In addition, the CC genotype was also found to be associated with greater ACS severity, including more stenosed vessels, greater occlusion of the left anterior descending branch, and a greater risk of anterior wall myocardial infarction (Table 5).

Other studies reported that CC genotype is to be associated with atherosclerosis [25], arterial hypertension [27], and coronary artery disease $[12,33]$.

Positive associations between A1166C polymorphism and disease may be the result of linkage disequilibrium with another polymorphism of functional importance, either within the AT1R gene or within a nearby one [34]. The A/C transversion per se does not characterize any functional diversity. Although there is no evidence to support this hypothesis, this polymorphism can be considered as a possible marker, in linkage disequilibrium with other functionally relevant genetic variants, affecting the structure or expression of the AT1R.

Finally, we focused this study on the effect of AT1R A/C polymorphisms on sudden cardiac death within 24 hours of ACS patients registered in the emergency room. AT1R CC genotype carriers had a higher mortality risk than AC or AA carriers. Genetic polymorphisms in AT1R-related genes have been independently associated with higher risk of MI-related sudden cardiac arrest.

\section{Conclusions}

In summary, this case-control study showed that the AT1R CC genotype was an independent risk factor for ACS incidence and especially for acute MI. In addition, the AT1R CC genotype was associated with greater ACS severity and 
a greater risk of sudden cardiac death. This experience of patients requiring urgent ACS treatment suggests that AT1R CC genotype carriers should be followed up and treated especially carefully because of the higher relative risk of more severe ACS and sudden cardiac death. Further studies are necessary to evaluate the personal pharmacogenomic and pharmacogenetic effects of ATIR A/C polymorphisms to improve ACS therapeutic strategies and prognosis. In future, examination of this polymorphism could become a part of the risk stratification of patients with acute coronary syndromes and predictor of sudden cardiac death.

\section{Disclosure}

This study was elaborated within the projects.

\section{Conflict of Interests}

The authors declare that they have no conflict of interests.

\section{Acknowledgment}

This work was supported by Grant of European Regional Development Fund-Project FNUSA ICRC (no. CZ.1.05/ 1.1.00/02.0123) and VEGA 2/0190/11.

\section{References}

[1] E. Braunwald, Ed., Heart Disease: A Textbook of Cardiovascular Medicine, WB Saunders, Philadelphia, Pa, USA, 1997.

[2] E. Ambrosioni, S. Bacchelli, D. D. Esposti, and C. Borghi, "ACEinhibitors and atherosclerosis," European Journal of Epidemiology, vol. 8, no. 1, pp. 129-133, 1992.

[3] T. W. Kurtz, “The ACE of hearts," Nature, vol. 359, no. 6396, pp. 588-589, 1992.

[4] D. R. J. Singer, C. G. Missouris, and S. Jeffery, "Angiotensinconverting enzyme gene polymorphism: what to do about all the confusion?" Circulation, vol. 94, no. 3, pp. 236-239, 1996.

[5] M. M. Morales-Suárez-Varela, M. L. Mansego, A. M. VicedoCabrera et al., "Inefficient arterial hypertension control in patients with metabolic syndrome and its link to renin-angiotensin-aldosterone system polymorphisms," Hypertension Research, vol. 34, no. 6, pp. 758-766, 2011.

[6] I. A. Reid, "The renin-angiotensin system: physiology, pathophysiology, and pharmacology," The American Journal of Physiology, vol. 275, no. 6, pp. S236-S245, 1998.

[7] M. G. Nicholls, A. M. Richards, and M. Agarwal, “The importance of the renin-angiotensin system in cardiovascular disease," Journal of Human Hypertension, vol. 12, no. 5, pp. 295-299, 1998.

[8] A. Bonnardeaux, E. Davies, X. Jeunemaitre et al., "Angiotensin II type 1 receptor gene polymorphisms in human essential hypertension," Hypertension, vol. 24, no. 1, pp. 63-69, 1994.

[9] A. T. Chiu, W. F. Herblin, D. E. McCall et al., "Identification of angiotensin II receptor subtypes," Biochemical and Biophysical Research Communications, vol. 165, no. 1, pp. 196-203, 1989.

[10] N. Ranjith, R. J. Pegoraro, L. Rom, P. A. Lanning, and D. P. Naidoo, "Renin-angiotensin system and associated gene polymorphisms in myocardial infarction in young South African Indians," Cardiovascular Journal of South Africa, vol. 15, no. 1, pp. 22-26, 2004.
[11] M. A. de Araújo, B. S. Menezes, C. Lourenço, E. R. Cordeiro, R. Rispoli Gatti, and L. R. Goulart, "The A1166C polymorphism of the angiotensin II type-1 receptor in acute myocardial infarction," Arquivos Brasileiros de Cardiologia, vol. 83, no. 5, pp. 404408, 2004.

[12] M. Buraczyńska, Z. Pijanowski, D. Spasiewicz et al., "Reninangiotensin system gene polymorphisms: assessment of the risk of coronary heart disease," Kardiologia Polska, vol. 58, no. 1, pp. 1-9, 2003.

[13] K. E. Berge, A. Bakken, M. Bøhn, J. Erikssen, and K. Berg, "A DNA polymorphism at the angiotensin II type 1 receptor (AT1R) locus and myocardial infarction," Clinical Genetics, vol. 52, no. 2, pp. 71-76, 1997.

[14] L. Tiret, A. Bonnardeaux, O. Poirier et al., "Synergistic effects of angiotensin-converting enzyme and angiotensin-II type 1 receptor gene polymorphisms on risk of myocardial infarction," The Lancet, vol. 344, no. 8927, pp. 910-913, 1994.

[15] C. W. Hamm, J. P. Bassand, S. Agewall et al., "ESC Guidelines for the management of acute coronary syndromes in patients presenting without persistent ST-segment elevation: the task force for the management of acute coronary syndromes (ACS) in patients presenting without persistent ST-segment elevation of the european society of cardiology (ESC)," European Heart Journal, vol. 32, no. 23, pp. 2999-3054, 2011.

[16] P. G. Steg, S. K. James, D. Atar et al., "ESC Guidelines for the management of acute myocardial infarction in patients presenting with ST-segment elevation," European Heart Journal, vol. 33, no. 20, pp. 2569-2619, 2012.

[17] G. Mancia, G. de Backer, A. Dominiczak, R. Cifkova, R. Fagard, and G. Germano, "Guidelines for the management of arterial hypertension: the task force for the management of arterial hypertension of the european society of hypertension and of the european society of cardiology," Journal of Hypertension, vol. 25, pp. 1105-1187, 2007.

[18] L. Rydén, E. Standl, B. Małgorzata et al., "Guidelines on diabetes, pre-diabetes, and cardiovascular diseases: executive summary. The task force on diabetes and cardiovascular diseases of the european society of cardiology (ESC) and of the european association for the study of diabetes (EASD)," European Heart Journal, vol. 28, no. 1, pp. 88-136, 2007.

[19] Z. Reiner, A. L. Catapano, G. de Backer et al., "ESC/EAS Guidelines for the management of dyslipidaemias. The task force for the management of dyslipidaemias of the european society of cardiology (ESC) and the european atherosclerosis society (EAS)," European Heart Journal, vol. 32, no. 4, pp. 1769-1818, 2011.

[20] D. F. Guo, Y. L. Sun, P. Hamet, and T. Inagami, "The angiotensin II type 1 receptor and receptor-associated proteins," Cell Research, vol. 11, no. 3, pp. 165-180, 2001.

[21] W. C. Paxton, Ruglssi, C. Horulst et al., "Imunohistochemical localization of rat angiotensin II at 1 receptor," The American Journal of Physiology, vol. 264, pp. 989-995, 1993.

[22] R. Ross, "Atherosclerosis: an inflammatory disease," The New England Journal of Medicine, vol. 340, no. 2, pp. 115-126, 1999.

[23] Z. N. Jiang, W. S. Zhao, F. Yu, and G. Xu, "Association of angiotensin II type 1 receptor gene polymorphism with essential hypertension," Chinese Medical Journal, vol. 114, no. 12, pp. 1249-1251, 2001.

[24] Y. Tanaka, K. Tamura, Y. Koide et al., “The novel angiotensin II type 1 receptor (AT1R)-associated protein ATRAP downregulates AT1R and ameliorates cardiomyocyte hypertrophy," FEBS Letters, vol. 579, no. 7, pp. 1579-1586, 2005. 
[25] J. Yu, G. N. Prado, L. Taylor, R. Pal-Ghosh, and P. Polgar, "Hybrid formation between the intracellular faces of the bradykinin B2 and angiotensin II AT1 receptors and signal transduction," International Immunopharmacology, vol. 2, no. 13-14, pp. 1807-1822, 2002.

[26] T. Mizuno, M. Makino, Y. Fujiwara et al., "Renin-angiotensin system gene polymorphism in Japanese stroke patients," International Congress Series, vol. 1252, pp. 83-90, 2003.

[27] A. Jones, S. S. Dhamrait, J. R. Payne et al., "Genetic variants of angiotensin II receptors and cardiovascular risk in hypertension," Hypertension, vol. 42, no. 4, pp. 500-506, 2003.

[28] J. A. Duncan, J. W. Scholey, and J. A. Miller, "Angiotensin II type 1 receptor gene polymorphisms in humans: physiology and pathophysiology of the genotypes," Current Opinion in Nephrology and Hypertension, vol. 10, no. 1, pp. 111-116, 2001.

[29] M. S. Ulgen, O. Ozturk, M. Yazici et al., "Association between A/C1166 gene polymorphism of the angiotensin II type 1 receptor and biventricular functions in patients with acute myocardial infarction," Circulation Journal, vol. 70, no. 10, pp. 1275-1279, 2006.

[30] R. Álvarez, J. R. Reguero, A. Batalla et al., "Angiotensin-converting enzyme and angiotensin II receptor 1 polymorphisms: association with early coronary disease," Cardiovascular Research, vol. 40, no. 2, pp. 375-379, 1998.

[31] A. Gardemann, Q. D. Nguyen, J. Humme et al., "Angiotensin II type 1 receptor A1166C gene polymorphism. Absence of an association with the risk of coronary artery disease and myocardial infarction and of a synergistic effect with angiotensin-converting enzyme gene polymorphism an the risk of these diseases," European Heart Journal, vol. 19, no. 11, pp. 1657-1665, 1998.

[32] G. I. Rice, C. A. Foy, and P. J. Grant, "Angiotensin converting enzyme and angiotensin II type 1-receptor gene polymorphisms and risk of ischaemic heart disease," Cardiovascular Research, vol. 41, no. 3, pp. 746-753, 1999.

[33] J. E. Eichner, V. J. Christiansen, W. E. Moore, S. T. Dunn, and E. Schechter, "Angiotensin-converting enzyme gene polymorphism in a cohort of coronary angiography patients," Atherosclerosis, vol. 154, no. 3, pp. 673-679, 2001.

[34] M. Castellano, M. L. Muiesan, M. Beschi et al., "Angiotensin II type 1 receptor A/C1166 polymorphism: relationships with blood pressure and cardiovascular structure," Hypertension, vol. 28, no. 6, pp. 1076-1080, 1996. 


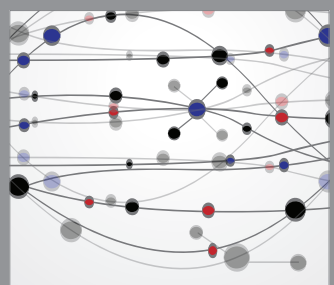

The Scientific World Journal
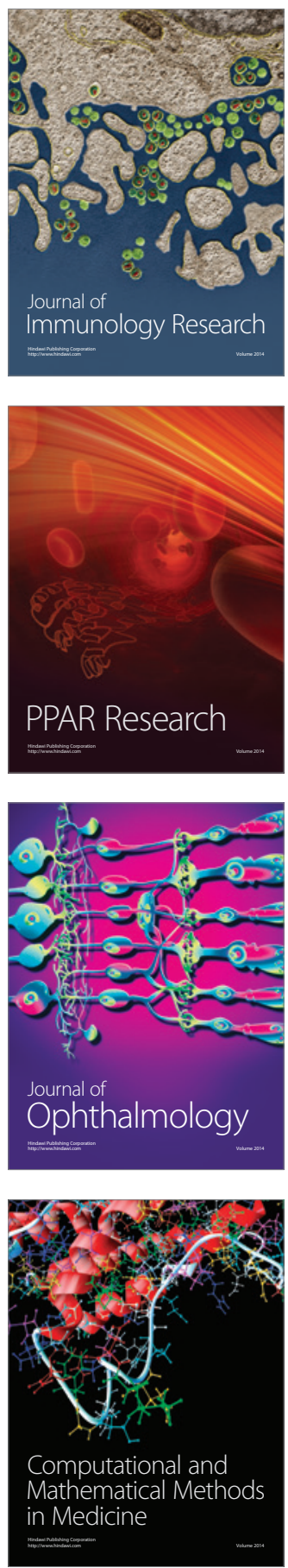

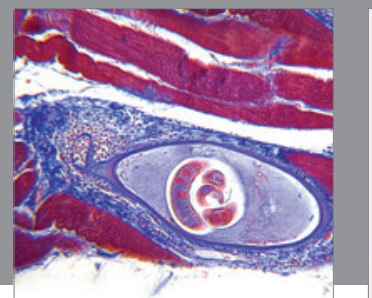

Gastroenterology

Research and Practice
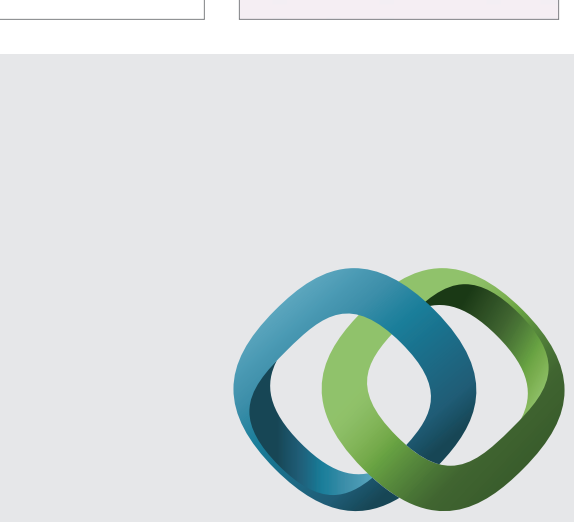

\section{Hindawi}

Submit your manuscripts at

http://www.hindawi.com
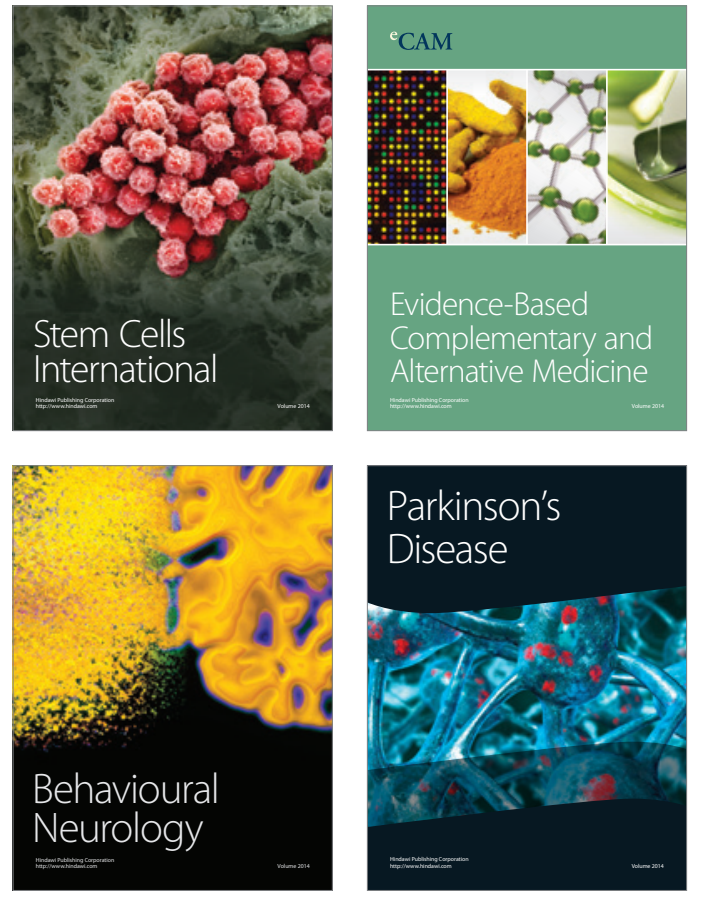
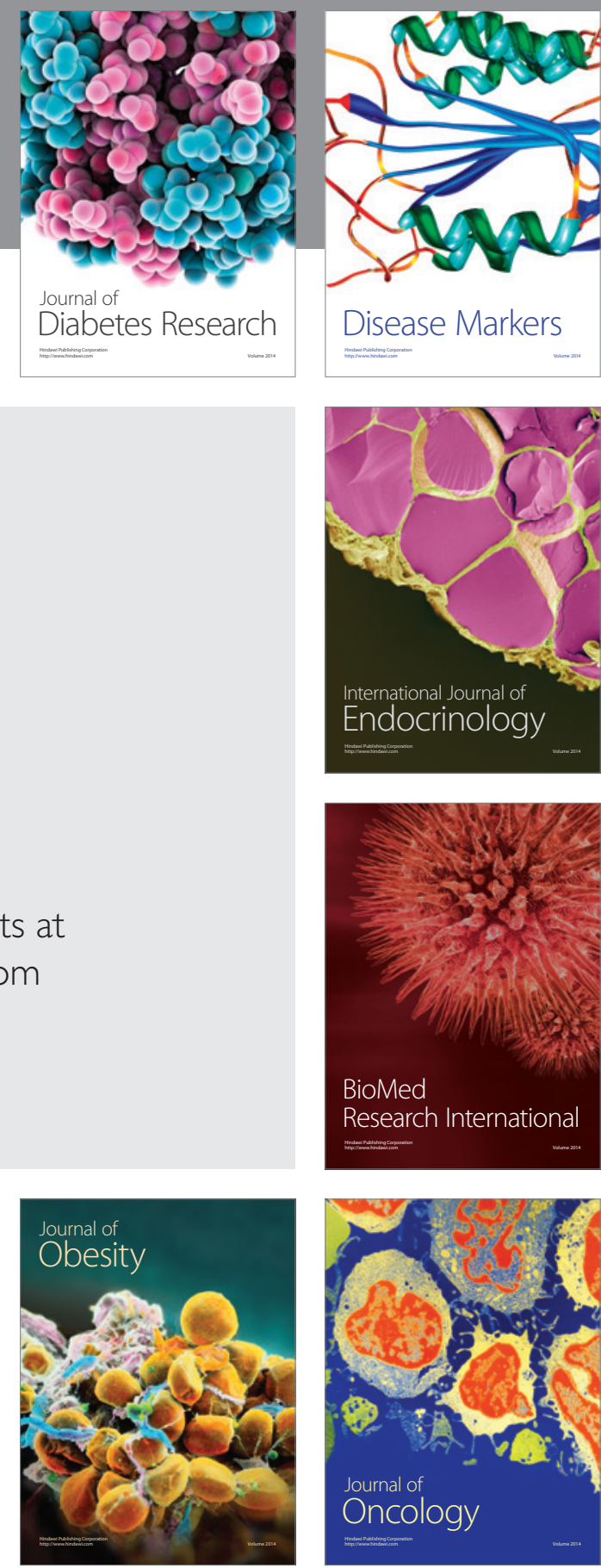

Disease Markers
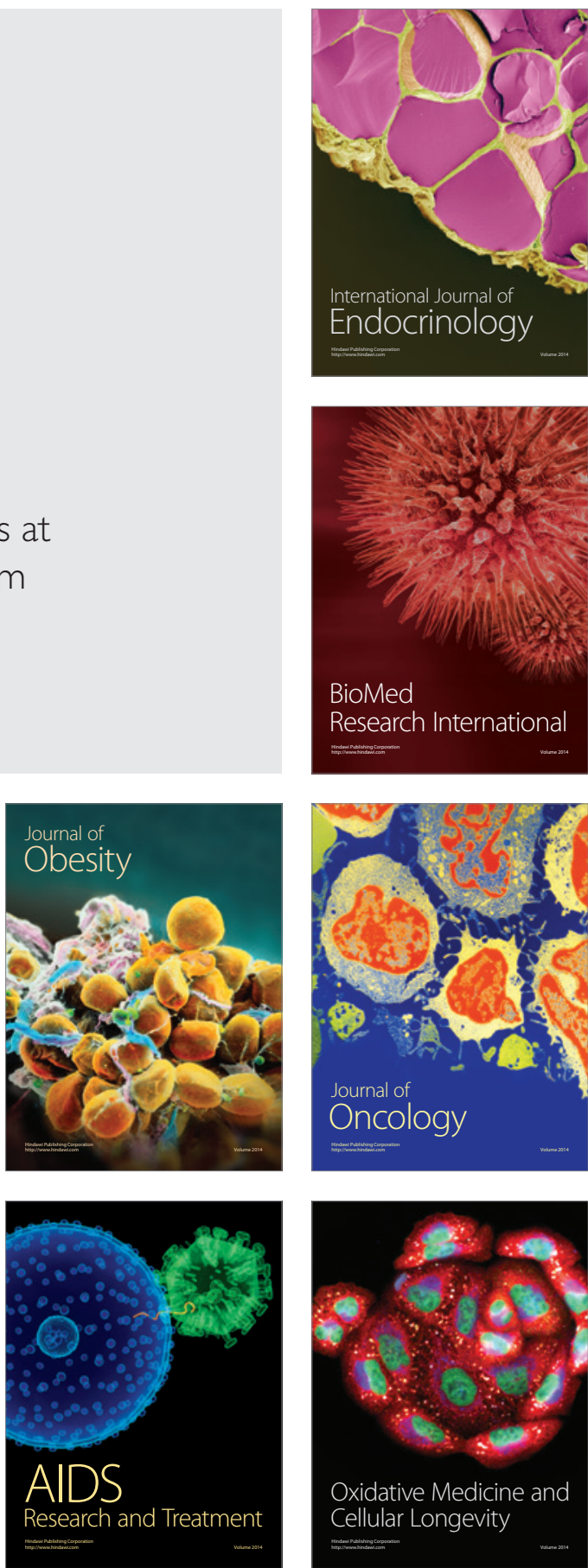